九州大学学術情報リポジトリ

Kyushu University Institutional Repository

\title{
A NEW SPECIES OF ANDRENA FROM JAPAN (HYMENOPTERA, ANDRENIDAE)
}

Tamasawa, Shusaburo

Hirashima, Yoshihiro

https://doi.org/10.5109/2456

出版情報: ESAKIA. 22，pp.103-105，1984-11-20. Entomological Laboratory，Faculty of Agriculture, Kyushu University バージョン :

権利関係 : 


\title{
A NEW SPECIES OF ANDRENA FROM JAPAN (HYMENOPTERA，ANDRENIDAE)*
}

\author{
SHUSABURo TAMASAwa \\ 4-38, Inano, Itami-City 664, Hyogo, Japan \\ and \\ Y OSHIHIRO HIRASHIMA \\ Entomological Laboratory, Faculty of Agriculture, \\ Kyushu University, Fukuoka 812. Japan
}

\begin{abstract}
A new species, Andrena (Euandrena) tateyamuna, is described from the subalpine region of central Honshu, Japan.
\end{abstract}

In 1979 and again in 1981, one of us, Tamasawa, was able to collect a new species of Andrena on Mt. Tateyama, Toyama Prefecture, central Honshu, Japan. The description of it is given in this paper.

\section{Andrena (Euandrena) tateyamana, new species}

Female : Length 9.5-10.5 mm.

Color : Black except as follows : mandibles reddened apically; flagellum piceous beneath; wings pale brownish subhyaline except paler basal portions ; veins and stigma pale brown ; subcosta fuscous ; tegulae piceous or slightly paler, reddish brown posteriorly ; small segments of tarsipiceous; tibial spurs distinctly yellowish ; apical margins of metasomal terga and sterna brownish subhyaline.

Pubescence : Hairs on head and thorax more or less dense and long in fresh specimens, dull white with slightly yellowish tinge, much paler than in takachihoi; fuscous hairs on sides of face, frons, vertex, genal area, mesoscutum and scutellum not usually very distinct ; hairs on propodeum long, not specially dense ; propodeal corbicula poor as usual for Euandrena; legs with hairs on trochanters and femora white, on tibiae and tarsi brownish except for hind tibial scopa which is well developed, white with yellowish tint ; dorsobasal portion of hind tibia and apex of hind femur with

* Contribution from the Entomological Laboratory, Faculty of Agriculture, Kyushu University, Fukuoka (Ser. 3, No. 159). 
hairs fuscous ; hairs on metasoma rather sparse ; apical margins of 3rd and 4th terga with broad, loose fringes of white hairs ; apical margin of 2 nd tergum with similar fringe of hairs on lateral portion only ; caudal fimbria fuscous.

Structure : Head slightly narrower than thorax in dorsal view ; face slightly longer than in takachihoi, slightly shorter than in hebes ; inner margins of eyes subparallel ; mandible rather robust, as usual ; malar space narrow, slightly broader than in takachihoi ; process of labrum transverse, broad, broader than in takachihoi, flat with entire apex ; facial fovea broad, rather shallow (narrow and deep in takachihoi) ; 1st flagellar segment about as long as next two segments together ; genal area more or less well developed. Apical transverse groove of pronotum entire ; propodeal enclosure not well defined as usual for Euandrena, large, with lateral margin almost straight (usually incurved in Japanese Euandrena); enclosure densely, irregularly wrinkled on basal half, granulate on apical half. Clypeus well convex, nearly smooth, shining and
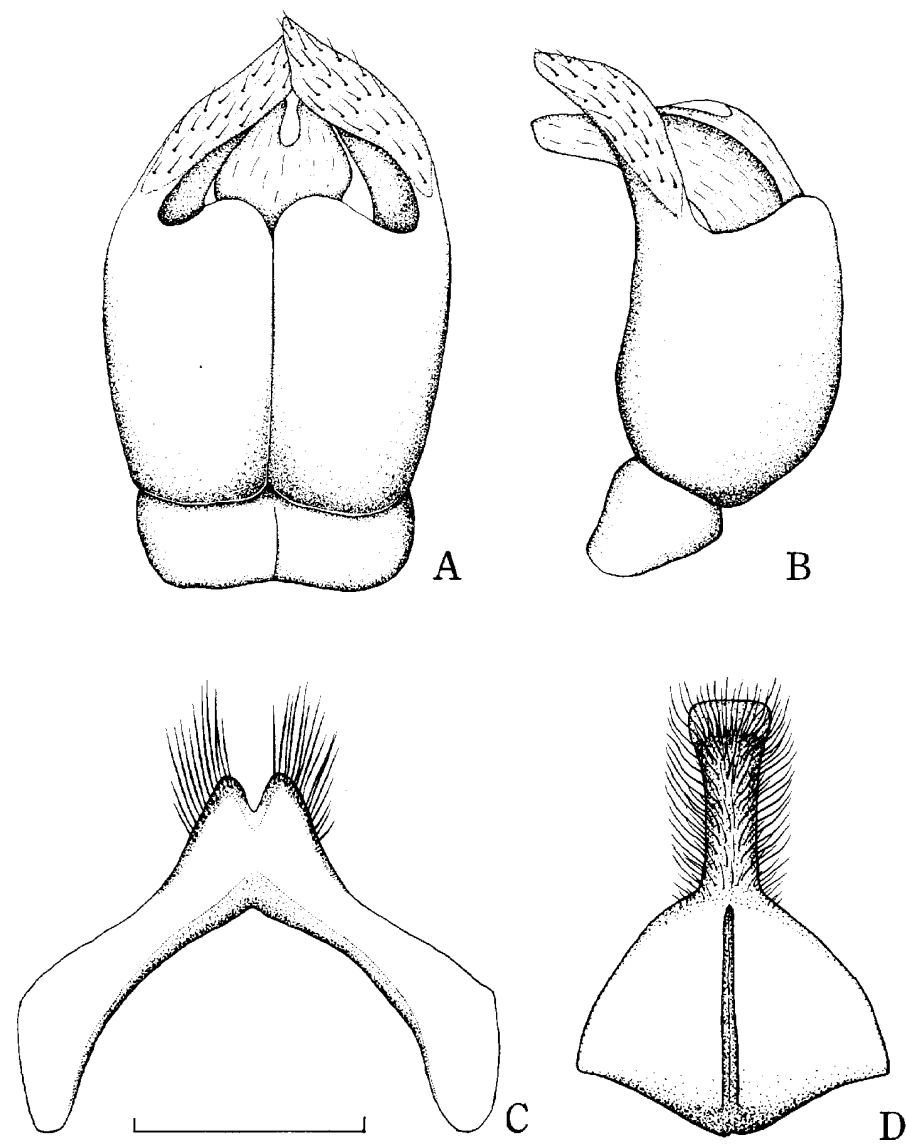

Fig. 1. Andrena (Euandrena) tateyamana, new species. A and B : male genital capsule, dorsal and lateral view ; C : male 7th sternum ; D: male 8th sternum. 
weakly punctate on median portion (more or less similar to hebes and stellaria, smoother and less punctate than in takachihoi); thorax shagreened or roughened with weak, not distinct punctures as usual for Japanese Euandrena; 1st metasomal terga more or less smooth, shining, with very weak and sparse punctures ; 2nd tergum like 1st but more punctate ; 3rd like 2nd but more granular, still shining ; 4th slightly more granular than 3rd.

Male : Length 8.5-9 $\mathrm{mm}$.

Flagellum elongate, 1st segment fuscous, darker than 2nd and following segments, longer than broad, a little longer than 2nd which is longer than broad and a little shorter than 3rd. Clypeus slightly more punctate and more granular than in female ; metasomal terga without distinct fringe of hairs on apical margins ; hairs on apical portion of metasoma much paler than in female.

Male genitalia and associated structures are as illustrated.

Type MATERial: Holotype female (Type No. 2468), 4 paratopotype females and 2 paratopotype males, Mt. Tateyama, Toyama Pref., 12. viii. 1981 (S. Tamasawa). Paratypes :1 female, Murodo, 2,400 m, Mt. Tateyama, Toyama Pref., on the flower of Ixelis sp., 19. viii. 1979 (S. Tamasawa) ; 1 male, Midagahara, 2,100 m, Mt. Tateyama, Toyama Pref., 20. viii. 1980, on the flower of Ixelis sp. (S. Tamasawa).

Distribution: Japan (subalpine region of Mt. Tateyama, central Honshu).

FLOWER RECORD: Lactuca (= Ixelis) sp.

Diagnosis : This is the fifth species of Euandrena of Japan. The new species, tateyamana, may be recongnizable from other members of Japanese Euandrena by the largest size and the stronger basal wrinkles of the propodeal enclosure in both sexes. Moreover, the female head is shorter and the male genitalia and associated structures are characteristic, as illustrated. The presence of fuscous hairs on the mesoscutum, although not usually distinct, is one of the characteristics of this new species.

\section{Acknowledgements}

We are grateful to Dr. 0. Tadauchi and Mr. S. Naomi of Kyushu University for illustrations of male genitalia and associated structures. We also thank Mr. Toshio Takada, Chief, Itami City Institute of Education, for the name of plant. 